\title{
ZBTB16/RARA Fusion Gene
}

National Cancer Institute

\section{Source}

National Cancer Institute. ZBTB16/RARA Fusion Gene. NCI Thesaurus. Code C99371.

A fusion gene that results from a chromosomal translocation $t(11 ; 17)(q 23 ; q 21)$ which fuses the 5' portion of the ZBTB16 gene to exon 4 of the RARA gene. This rearrangement is associated with acute promyelocytic leukemia. 